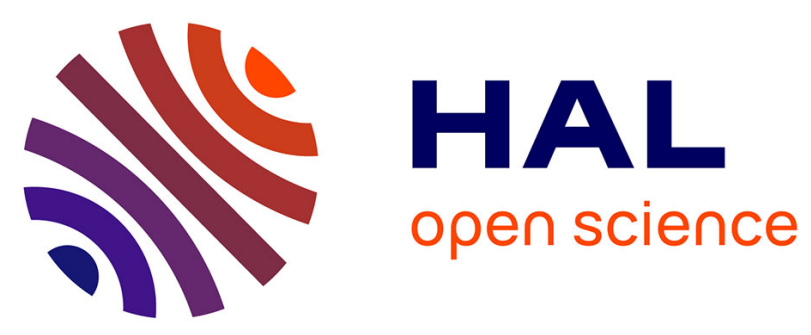

\title{
Corticosterone, prolactin and egg neglect behavior in relation to mercury and legacy POPs in a long-lived Antarctic bird
}

Sabrina Tartu, Frédéric Angelier, John C. Wingfield, Paco Bustamante, Pierre Labadie, Hélène Budzinski, Henri Weimerskirch, Jan Ove Bustnes, Olivier Chastel

\section{To cite this version:}

Sabrina Tartu, Frédéric Angelier, John C. Wingfield, Paco Bustamante, Pierre Labadie, et al.. Corticosterone, prolactin and egg neglect behavior in relation to mercury and legacy POPs in a long-lived Antarctic bird. Science of the Total Environment, 2015, 505, pp.180 - 188. 10.1016/j.scitotenv.2014.10.008 . hal-01104653

\section{HAL Id: hal-01104653 https://hal.science/hal-01104653}

Submitted on 18 Jan 2015

HAL is a multi-disciplinary open access archive for the deposit and dissemination of scientific research documents, whether they are published or not. The documents may come from teaching and research institutions in France or abroad, or from public or private research centers.
L'archive ouverte pluridisciplinaire HAL, est destinée au dépôt et à la diffusion de documents scientifiques de niveau recherche, publiés ou non, émanant des établissements d'enseignement et de recherche français ou étrangers, des laboratoires publics ou privés. 


\section{Corticosterone, prolactin and egg neglect behaviour in}

\section{relation to mercury and legacy POPs in a long-lived}

\section{Antarctic bird}

S. Tartu ${ }^{1 *}$, F. Angelier ${ }^{1}$, J.C. Wingfield ${ }^{2}$, P. Bustamante ${ }^{3}$, P. Labadie ${ }^{4,5}$, H. Budzinski $^{4,5}, \mathrm{H}$. Weimerskirch ${ }^{1}$, J.O. Bustnes ${ }^{6}$ and O. Chastel $^{1}$

${ }^{1}$ UMR 7372 - CNRS-Université de La Rochelle, Villiers-en-bois, France

${ }^{2}$ Department of Neurobiology, Physiology and Behaviour, University of California, Davis, USA

${ }^{3}$ Littoral Environnement et Sociétés (LIENSs), UMR 7266 CNRS-Université de la Rochelle, La Rochelle, France

${ }^{4}$ Université de Bordeaux, EPOC/LPTC, UMR 5805, F-33400 Talence, France

${ }^{5}$ CNRS, EPOC/LPTC, UMR 5805, F-33400 Talence, France

${ }^{6}$ Norwegian Institute for Nature Research, FRAM - High North Research Centre on Climate and the Environment, NO-9296 Tromsø, Norway

*Corresponding author: tartu.sabrina@gmail.com 


\begin{abstract}
Seabirds often have high loads of contaminants. These contaminants have endocrine disrupting properties but their relationships with some endocrine mechanisms are still poorly investigated in free-living organisms. This is the case for the stress response which shifts energy investment away from reproduction and redirects it towards survival. In birds, this stress response is achieved through a release of corticosterone and is also accompanied by a decrease in circulating prolactin, an anterior pituitary hormone widely involved in regulating parental cares. We measured blood concentrations of some legacy persistent organic pollutants (POPs) and mercury ( $\mathrm{Hg}$ ) and examined their relationships with the corticosterone and prolactin responses of known-age (9-46 years old) incubating snow petrels (Pagodroma nivea) to a standardized capture/handling stress protocol. In this Antarctic seabird, we also investigated whether high contaminant burden correlates with a higher occurrence of egg neglect, a frequently observed behaviour in snow petrels. POPs and $\mathrm{Hg}$ were unrelated to age. Stress-induced corticosterone concentrations were positively related to POPs in both sexes, and stress-induced prolactin concentrations were negatively related to $\mathrm{Hg}$ in males. Eggneglect behaviour was not related to POPs burden, but males with higher $\mathrm{Hg}$ concentrations were more likely to neglect their egg. This suggests that in birds, relationships between age and contaminants are complex and that even low to moderate concentrations of POPs and $\mathrm{Hg}$ are significantly related to hormonal secretion. In this Antarctic species, exposure to legacy POPs and $\mathrm{Hg}$ could make individuals more susceptible to environmental stressors such as ongoing disturbances in polar regions.
\end{abstract}

Keywords: Snow petrel, Mercury, Persistent organic pollutants, Age, Reproduction 


\section{INTRODUCTION}

The parental phase is energy-demanding (Drent and Daan 1980) and individuals adopt different life-history strategies in order to cope with environmental stressors such as food shortage, predation or poor weather. In extreme environments, such as Polar Regions, animals often experience harsh and unpredictable environmental conditions, and as a result long-lived organisms such as seabirds may refrain from breeding or desert their brood (e.g Angelier et al. 2007; Goutte et al. 2011a). At the physiological level, the release of glucocorticoid hormones (cortisol, corticosterone: CORT) during stressful events triggers physiological and behavioral adjustments that shift energy investment away from reproduction and redirects it towards selfpreservation and hence survival (Angelier and Wingfield, 2013; Ricklefs and Wikelski, 2002; Wingfield and Sapolsky, 2003). Stress hormones have therefore a strong connection to fitness traits such as breeding success, individual quality and survival (Angelier et al. 2009a, 2010; Bonier et al. 2009; Bókony et al. 2009; Breuner et al. 2008; Goutte et al. 2010, 2011b; Kitaysky et al. 1999). Additionally, the hormone prolactin (PRL) can also mediate this lifehistory trade-off between reproduction and survival in free-living birds (reviewed in Angelier and Chastel 2009). The release of this anterior pituitary hormone stimulates and facilitates parental behaviour such as egg incubation and brood provisioning (Buntin 1996). In response to acute stress, circulating PRL levels has been shown to decrease in several bird species (Angelier et al. 2013; Chastel et al. 2005), and this could ultimately trigger nest desertion if PRL levels remain low during a prolonged period (Angelier et al. 2007; 2009b; Angelier and Chastel 2009; Heidinger et al. 2010). Importantly, this decrease in PRL levels varies between individuals and life-history stages, suggesting that birds can attenuate their PRL response to acute stress to ensure that reproduction is not inhibited when the fitness value of the current reproductive event is high (the 'brood value hypothesis'; Bókony et al. 2009; Lendvai et al. 2007). Thus, both CORT and PRL are very likely to mediate parental effort and parental 
investment in birds (Angelier et al. 2007, 2009b, 2013; Chastel et al. 2005; Criscuolo et al. 2005; Groscolas et al. 2008; Koch et al. 2004) and any disruption of these major endocrine cascades may alter the ability of an individual to adjust reproductive decisions to environmental conditions (Jenssen 2005; Tartu et al. 2013).

In addition to extreme environmental conditions, climate change and anthropogenic disturbances (Clarke and Harris 2003; Moline et al. 2008; Smetacek and Nicol 2005), polar species are subjected to environmental pollution. Indeed, despite their remote location, polar areas are the fall-out region of contaminants which undergo long range transport such as persistent organic pollutants (POPs) and heavy metals (e.g. mercury: Hg). Indeed, because of climate characteristics, contaminants accumulate in the polar environment, where they may be bio-accumulated and for some compounds bio-magnified (Bargagli 2008; Gordeev 2002; Risebrough et al. 1976; Wania and Mackay 1996; Wania 2003). Moreover, long-lived organisms are thought to be highly sensitive to contaminants (Rowe 2008), but there are surprisingly few data on the effect of age on contaminant levels, and it is not clear if seabirds accumulate POPs with increasing age (Bustnes et al., 2003a).

Marine apex predators, such as seabirds, are particularly exposed (Gabrielsen 2007; Rowe 2008; van den Brink et al. 1997) and several studies have reported breeding impairments in highly polluted seabirds (Bustnes et al. 2001, 2003b, 2007; Tartu et al. 2013; Verboven et al. 2009). Such breeding impairments could originate from the ability of contaminants to act as endocrine disruptors and thus, to alter the functioning of endocrine axes (Guillette and Gunderson 2001; Ottinger et al. 2002, 2013; Tan et al. 2009; Tartu et al. 2013, 2014; Tyler et al. 1998). Experimental studies have documented some effects of chemicals on glucocorticoids (Love et al. 2003; Odermatt and Gumy, 2008), but the effects of contaminants on stress hormones in free-living organisms such as seabirds have rarely been studied (Bergman et al. 2013; Nordstad et al. 2012; Tartu et al. 2014; Verboven et al. 2010). It 
is therefore difficult to draw a general pattern of the relationships between contaminants and stress hormones.

Regarding the effects of contaminants on PRL, the knowledge is even poorer and only one study (Verreault et al. 2008) has addressed relationships between PRL secretion and POPs. In glaucous gulls (Larus hyperboreus) baseline PRL levels and the rate of decrease in PRL levels tended to vary negatively with organohalogen contaminants in males only (Verreault et al. 2008). Furthermore, numerous compounds are potential environmental contaminants (e.g. heavy metals, POPs), which may have different effects on hormones of the hypothalamopituitary-adrenal (HPA) axis, such as CORT but also PRL secretion. There is thus a need to determine whether different environmental contaminants can disrupt these hormones in freeliving organisms. The aim of this study was to investigate the potential roles of environmental contaminants such as $\mathrm{Hg}$ and some legacy POPs (i.e. polychlorinated biphenyls: PCBs; organochlorine pesticides: OCPs; and polybrominated diphenyl ethers: PBDEs) on two major endocrine mechanisms: stress hormones from the HPA axis: CORT, and a key pituitary 'parental hormone': PRL. The snow petrel (Pagodroma nivea) a contaminated Antarctic seabird (Xie et al. 2008; Corsolini et al. 2011; Goutte et al. 2013, Tartu et al. unpublished data) provides an ideal species to address these questions. In this long-lived species (until 50 years old, Chastel et al. 1993), CORT and PRL responses to acute stress are modulated in relation to parental investment and incubation commitment (Angelier et al. 2007; Goutte et al. 2011c). For example, low stress-induced PRL levels are associated with a high probability of egg neglect, a frequently observed behaviour in snow petrels (Angelier et al. 2007). Further, thanks to an exceptional long-term banding survey (1964-present; Barbraud and Weimerskirch 2001; Chastel, et al. 1993), many snow petrels are of known age, making it possible to address the effect of age on contaminant burden. 
In that context, we investigated if POPs and/or $\mathrm{Hg}$ concentrations were related to 1) age, 2) CORT and/or PRL secretion and 3) parenting through egg-neglect behaviour. We predicted that POPs and/or Hg: 1) would increase with increasing age as a result of bio-accumulation; 2) would increase CORT and decrease PRL secretion; 3) would be higher in individuals that neglected their egg.

\section{MATERIALS AND METHODS}

\section{Ethics statement}

Animals were cared for in accordance with the guidelines of the ethics committee of the Institut Polaire Français Paul Emile Victor (IPEV) that specifically approved this study (Program no. 109, H. Weimerskirch).

\section{Study site, blood sampling and body-condition}

Snow petrels are Antarctic seabirds with a delayed sexual maturity ( 10 years of age), a low fecundity (one egg per clutch and a maximum of one clutch per year) and a long lifespan ( 50 years old) (Chastel et al. 1993). Adult males and females were handled during the 2010 late incubation period (8-21 January). A total of 49 birds (27 males and 22 females) were caught in 49 different nests and age was known for 47 of them (9-46 years old). Birds were captured by hand and were then bled according to the standardized capture/restraint stress protocol described by Wingfield (1994). Immediately after capture (i.e. within $3 \mathrm{~min}$ ), an initial blood sample $(300 \mu \mathrm{l})$ was collected from the alar vein with a 1-mL heparinized syringe and a 25gauge needle. These initial blood samples were considered to reflect baseline levels of CORT and PRL (Chastel et al. 2005; Romero and Reed 2005; thereafter called 'baseline' sample). After collection of the initial blood samples birds were placed into cloth bags, and a subsequent sample $(300 \mu \mathrm{l})$ was collected $30 \mathrm{~min}$ after capture (thereafter called 'stressinduced' sample). During handling of the adult birds, their eggs were covered with cotton and 
kept warm. After these blood samples, each bird was put back in its nest. Snow petrels are tame and usually resume parental duties as soon as returned to their nest (e.g. Angelier et al. 2007). After this acute stress protocol, petrels were left undisturbed at their nest for $20 \mathrm{~min}$ and were then captured again and blood sampled within 3 min of recapture (thereafter called 'post-stress' sample) to monitor how quickly hormone levels may return to baseline after a stressor. This blood sample was taken before CORT and PRL concentrations returned to normal, allowing us to effectively monitor the stress recovery. All birds were weighed to the nearest $2 \mathrm{~g}$ using a spring balance and their skull length (head + bill) was measured to the nearest $0.5 \mathrm{~mm}$. Body condition index (thereafter 'body condition') was calculated as the residuals between body mass and skull length (regression: $F_{1,47}=20.28, p<0.001, R^{2}=0.35$ ). After capture and blood sample, each nest was monitored twice a day until the manipulated petrel was relieved by its mate. We were therefore able to know whether a bird neglected its egg during the incubation bout following capture/restraint stress protocol (thereafter called 'egg neglect behaviour'). Leaving eggs unattended temporarily is common in Procellariiform birds (Boersma and Wheelwright 1979; Chaurand and Weimerskirch 1994). Distant foraging and unpredictable weather increase the probability to delay an individual's returning to relieve its incubating partner (Boersma and Wheelwright, 1979). Eggs left unattended for a long period are less likely to hatch successfully (Boersma and Wheelwright, 1979, Angelier et al. 2007). In snow petrels were egg-neglect is often observed (Angelier et al; 2007), both parents incubate the single egg four bouts lasting ca. 4 to 8 days while the partner is feeding at sea (Ryan and Atkins 1989). In two sampled birds, the egg was predated during the incubation bout following the capture/restraint stress protocol. Egg-neglect data were available for 47 birds. 


\section{Molecular sexing and hormone assay}

Blood samples were centrifuged, and plasma was decanted and stored at $-20^{\circ} \mathrm{C}$ until assayed. After centrifugation, red cells were kept frozen for molecular sexing as well as for $\mathrm{Hg}$ determination. The sex was determined by polymerase chain reaction amplification of part of two highly conserved genes (CHD) present on the sex chromosomes at UMR 7372 - CNRSUniversité de La Rochelle, as detailed in Weimerskirch et al. (2005). Plasma concentrations of CORT were determined first by radioimmunoassay at UMR 7372 - CNRS-Université de La Rochelle, as previously described (Lormée et al. 2003). Plasma concentrations of PRL were determined with the remaining plasma by a heterologous radioimmunoassay at UMR 7372 CNRS-Université de La Rochelle, as detailed in Cherel et al. (1994). The PRL assay has previously been validated in snow petrels (Angelier et al. 2007). All samples were run in one assay for both hormones. To measure intra-assay variation, we included 4 different referents 10 times in the CORT and PRL assays. From this, the intra-assay variation was $6.7 \%$ for total CORT and $7.8 \%$ for PRL. CORT and PRL concentrations were measured in baseline, stressinduced and post-stress samples.

\section{Organic pollutants determination in plasma}

POPs were measured in plasma samples collected from 15 females and 21 males only, since in 13 birds the remaining plasma volumes were too low. The targeted compounds included 7 indicator PCBs (CB-28, -52, -101, -118, -138, -153 and -180), 11 OCPs (HCB, Gamma HCH, Heptachlore, cis-chlordane, trans-nonachlor, 2,4' DDE, 4,4' DDE, 4,4' DDD, 2,4' DDT, 4,4' DDT and mirex) and two PBDE (BDE-47 and BDE-99). Certified solutions containing all analytes in isooctane at $2 \mathrm{ng} \bullet \mathrm{LL}^{-1}$ each were obtained from LGC Standards (Molsheim, France). To a plasma sample of $100 \mu \mathrm{L}$, internal standards (1 ng each) were added gravimetrically: CB-30, $-103,-155$ and -198 were used to quantify PCBs, p,p'-DDT-d8 was 
used to quantify OCPs and F-BDE-47 was used to quantify BDE-47 and BDE-99; standards were provided by either Dr Ehrenstorfer GmbH, Cambridge Isotope Laboratory (via Cluzeau Info Labo, Sainte-Foy-La-Grande, France) or Chiron (via BCP Instruments, Irigny, France). POPs were extracted with $1 \mathrm{~mL}$ of pentane:dichloromethane $(90: 10 ; \mathrm{v} / \mathrm{v})$; after centrifugation (2000 rpm, $2 \mathrm{~min}$ at $4^{\circ} \mathrm{C}$ ), the organic layer was collected and the operation was repeated. Both extracts were combined and purified on an acid silica gel column $\left(40 \% \mathrm{H}_{2} \mathrm{SO}_{4}\right)$. After extract loading, analytes were eluted with 3 x $5 \mathrm{~mL}$ of pentane/dichloromethane (90/10; v/v). Extracts were then concentrated using a RapidVap vacuum evaporation system from Labconco (Kansas City, MO, USA) to a volume of $1 \mathrm{~mL}$ and further concentrated under a gentle stream of nitrogen $\left(40^{\circ} \mathrm{C}\right)$ after addition of $100 \mu \mathrm{L}$ of isooctane as solvent keeper. Octachloronaphtalene (1 ng) was finally added to determine the recovery rate for each internal standard, for each sample (68-108\%). Final extracts were analysed by gas chromatography coupled with electron capture detection (GC-ECD) as described elsewhere (Tapie et al. 2011).

Quality control consisted in the analysis of standard solutions (NIST SRM 2261 and SRM 2262) and of procedural blanks (clean and empty glass tubes treated like a sample, one blank for 8 samples). Recoveries for standard solutions ranged from 89 to $104 \%$ with standard deviations lower than $13 \%(\mathrm{n}=4)$. Chicken plasma samples (Sigma-Aldrich, $\mathrm{S}^{\mathrm{t}}$ Quentin Fallavier, France) spiked with all analytes $\left(3 \mathrm{ng} \bullet \mathrm{g}^{-1}\right.$ each) were analysed; the recovery rates were in the range 77-103\% with coefficients of variation lower than $17 \%(n=5)$, except for CB-52 (22\%) and mirex (29\%). POP concentrations were blank corrected and the detection limit (LoD) was set at two times the mean blank value; for analytes that were not detected in blanks, LoD was determined as the concentration with a signal to noise ratio of 3 in spiked chicken plasma samples. Overall, LoDs ranged from 0.03 to $0.34 \mathrm{ng}_{\bullet} \mathrm{g}^{-1}$ wet weight (ww). Additionally, plasma total lipids were measured on an aliquot of $10 \mu \mathrm{L}$ by the sulfo-phosphovanillin (SPV) method for colorimetric determination (Frings et al. 1972). 


\section{Hg determination in blood cells}

Total Hg was measured as described in details in Bustamante et al. (2006). Briefly, from freeze-dried and powdered red blood cells (hereafter called 'blood') in an Advanced $\mathrm{Hg}$ Analyzer spectrophotometer (Altec AMA 254). At least two aliquots ranging from 5 to $10 \mathrm{mg}$ were analyzed for each individual and quality assessment was measured by repeated analyses of certified reference material TORT-2 (lobster hepatopancreas, NRCC; certified value $0.27 \pm 0.06 \mu \mathrm{g}_{\bullet} \mathrm{g}^{-1}$; with recoveries of 98 to $102 \%$ ) and blanks, empty sample container, run every 20 samples. Hg concentrations are expressed in $\mu \mathrm{g} \bullet \mathrm{g}^{-1}$ dry weight (dw).

\section{Statistical analyses}

All analyses were performed using R 2.13.1 (http://r-project.org/). We first tested intercorrelations between the different families of POPs detected by using linear models (LM). Second, we used generalized linear model (GLM) with normal errors and an identity link function to test whether $\Sigma$ POPs or $\mathrm{Hg}$ were influenced by sex, body-condition and age (dependent variable: $\Sigma$ POPs and $\mathrm{Hg}$, independent factor and variables: sex, body-condition and age). Third, we tested whether CORT and PRL kinetics differed between male and females by using repeated measures GLM with the time of sampling (baseline, stress-induced and post-stress levels) as the repeated measures; (dependent variable: CORT and PRL concentrations, independent factors: sex, time and their interaction). Fourth, we tested whether CORT concentration (baseline, stress-induced and post-stress) was related to $\Sigma$ POPs and $\mathrm{Hg}$ (dependent variable: CORT, independent factor and variables: $\mathrm{PPOPs}$, sex, age, $\mathrm{Hg}$, body-condition and their interaction with sex). For PRL we analysed males and females separately (dependent variable: PRL, independent variables: $\Sigma$ POPs, age, $\mathrm{Hg}$, body-condition) because in incubating snow petrels, females bear higher PRL concentrations than males (Angelier et al. 2007). Finally, we tested if the probability of neglecting the egg was related to ¿POPs and $\mathrm{Hg}$ in males and females separately (dependent variable: egg neglect; independent 
variables: $\Sigma$ POPs, age, $\mathrm{Hg}$, body-condition). To test the relationships between contaminants and egg-neglect behaviour (yes or no) we used GLM with binomial error and logit link. Dependent continuous variables were previously tested for normality with a Shapiro-Wilk test and were log-transformed when necessary. Selected models were then checked for assumptions, that is, constancy of variance and residual normality. We performed all our model selection starting from the most general model that included all the variables/factors of interest and their interactions and we removed step by step the non-significant interactions, variables or factors. For POPs statistical analyses, concentrations below LoD were assigned LoD value, and only compounds detected in at least $70 \%$ of the individuals were included into the sum of POPs (Noël et al. 2009).

\section{RESULTS}

\section{Contaminants: concentrations and compounds}

Out of the 20 POP targeted compounds, 15 could be detected but the concentrations of four OCPs (cis-chlordane, trans-nonachlor, heptachlor and 2,4'-DDE) and one PBDE (BDE-99) were systematically below LoD. The most abundant compounds were the PCBs, with the PCBs 101 and 118 reaching the highest concentrations, closely followed by CB-138 and CB153 (Table 1). Of the OCPs, HCB had the highest concentrations followed by 4,4'-DDE (Table 1). Only four PCBs (-CB101, -118, -138 and -153) and four OCPs (HCB, gamma $\mathrm{HCH}, 4,4^{\prime} \mathrm{DDE}$ and 2,4' DDT) were detected in at least $70 \%$ of the individuals and were thus included into the analyses. $\Sigma$ PCBs and $\Sigma$ OCPs were positively correlated (PCBs vs. OCPs: $\left.\mathrm{LM}, \mathrm{F}_{1,34}=18.1, \mathrm{p}<0.001, \mathrm{R}^{2}=0.35\right)$. Thus the global pollutant burden was described as a sum of POPs (hereafter ' $\Sigma$ POPs'). In incubating snow petrels, blood $\mathrm{Hg}$ averaged $1.91 \pm$ $0.75 \mu \mathrm{g} \bullet \mathrm{g}^{-1} \mathrm{dw}$, specifically in males $1.94 \pm 0.77 \mu \mathrm{g} \bullet \mathrm{g}^{-1} \mathrm{dw}$ (range: $0.89-4.01$ ) and in females $1.87 \pm 0.73 \mu \mathrm{g} \bullet \mathrm{g}^{-1} \mathrm{dw}$ (range: $0.74-3.70$ ). 


\section{Relationship between contaminants, sex, body-condition and age}

During the incubation period, $\Sigma$ POPs was not statistically different between male and female snow petrels $\left(\mathrm{GLM}, \mathrm{F}_{1,34}=3.21, \mathrm{p}=0.082\right)$. Hg concentrations were not related to sex neither (GLM, $\left.\mathrm{F}_{1,47}=0.12, \mathrm{p}=0.734\right) . \Sigma \mathrm{POPs}$ and $\mathrm{Hg}$ concentration, respectively, were unrelated to the body-condition index ( $\Sigma$ POPs: $\mathrm{F}_{1,34}=1.05, \mathrm{p}=0.313$, interaction with sex: $\mathrm{F}_{1,33}=2.18, \mathrm{p}=$ 0.149; Hg: $\mathrm{F}_{1,46}=3.30, \mathrm{p}=0.076$, interaction with sex: $\left.\mathrm{F}_{1,45}=0.14, \mathrm{p}=0.714\right) . \Sigma$ POPs were not related to age $\left(\mathrm{F}_{1,34}=0.88, \mathrm{p}=0.355\right.$, interaction with sex: $\left.\mathrm{F}_{1,33}=0.61, \mathrm{p}=0.441\right)$, and neither were $\mathrm{Hg}$ concentrations $\left(\mathrm{F}_{1,45}=2.05, \mathrm{p}=0.159\right.$ interaction with sex: $\mathrm{F}_{1,44}=0.16, \mathrm{p}=$ 0.693). Finally, $\Sigma$ POPs and $\mathrm{Hg}$ were not related $\left(\mathrm{F}_{1,34}=2.09, \mathrm{p}=0.157\right)$.

\section{CORT and PRL kinetics: response and recovery to acute stress protocol}

CORT concentrations significantly increased over $30 \mathrm{~min}$ from $4.7 \pm 3.4$ to $37.8 \pm 8.6 \mathrm{ng}_{\bullet} \mathrm{ml}^{-1}$ and then declined $20 \mathrm{~min}$ post-stress to $23.6 \pm 12.6 \mathrm{ng} \bullet \mathrm{ml}^{-1}\left(\mathrm{GLMM}\right.$, time as factor, $\mathrm{F}_{2,94}=$ 269.98, $\mathrm{p}<0.001$ ), without sex difference ( $\operatorname{sex}: \mathrm{F}_{1,47}=0.28, \mathrm{p}=0.600$; time $\times$ sex interaction: $\left.\mathrm{F}_{2,94}=0.08, \mathrm{p}=0.926\right)$. PRL concentrations significantly decreased over time (GLMM, time as factor, $\left.F_{2,94}=144.26, \mathrm{p}<0.001\right)$ and females had higher PRL concentrations than males $\left(\right.$ sex: $F_{1,47}=152.72, p<0.001 ;$ time $\times$ sex interaction: $\left.F_{2,94}=3.79, p=0.026\right)$. In females, PRL decreased from $239.5 \pm 36.3$ to $169.4 \pm 32.1 \mathrm{ng} \bullet \mathrm{ml}^{-1}$ after $30 \mathrm{~min}$ and until $165.4 \pm 30.8$ ng $\bullet \mathrm{ml}^{-1} 20$ min post-stress. In males PRL concentrations decreased from $139.5 \pm 30.7$ to 90.9

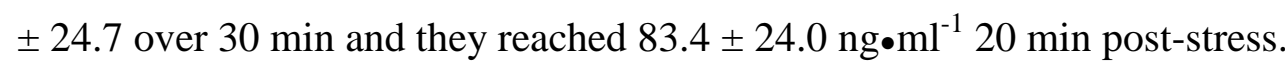

\section{Relationships between contaminants and CORT concentrations}

CORT absolute concentrations (baseline, stress-induced and post-stress) were not related to sex, neither to age, $\mathrm{Hg}$, body-condition and their interaction with sex (Table 2). $\Sigma$ POPs were not related to baseline CORT (Fig. 1.A, Table 2), but increasing concentration of $\Sigma$ POPs was 
positively related to increasing concentration of stress-induced and post-stress CORT (Fig. 1.B-C, Table 2).

\section{Relationships between contaminants, PRL concentrations and egg-neglect}

In females we did not find any relationship between PRL (baseline, stress-induced and poststress) and $\Sigma$ POPs, age, $\mathrm{Hg}$, or body-condition ( $\mathrm{p}>0.08$ for all tests). In males baseline and post-stress PRL concentrations were not related to $\Sigma$ POPs, age, $\mathrm{Hg}$, or body-condition ( $p>0.07$ for all tests), but increasing blood $\mathrm{Hg}$ concentration was related to decreasing stressinduced PRL concentration: i.e. after 30 min restraint the most contaminated males were less likely to maintain high concentrations of PRL (GLM, $F_{1,25}=5.6, p=0.0263$; Fig. 2). Eleven females and eight males were observed neglecting their egg, out of 21 and 26, respectively. Blood $\mathrm{Hg}$ concentration was higher in males that were more likely to neglect their egg (GLM, $\chi^{2}=, p=0.019$, Fig. 3) a relationship not found in females (GLM, $\chi^{2}=0.1, p=0.796$, Fig. 3). Finally, egg neglect behaviour was not related to $\mathrm{EPOPs}$, age or body-condition in any sex ( $\mathrm{p}>0.4$ for all tests).

\section{DISCUSSION}

The present study is the first to report plasma POP concentrations in the long-lived, Antarctic snow petrel. Firstly, there were no relationships between plasma $\Sigma$ POPs or blood $\mathrm{Hg}$ and age, suggesting that long-lived seabird are able to eliminate much of their contaminant burden. Secondly, $\Sigma$ POPs and $\mathrm{Hg}$ seem related to different hormonal pathways involved in reproductive decisions; $\Sigma$ POPs may disrupt the HPA axis whereas $\mathrm{Hg}$ was related to PRL secretion in males and consequently to egg-neglect behaviour. 


\section{Contaminants and age}

Although snow petrels are very long-lived and thus exposed to contaminants over many years, no evidence was found that contamination was age-related, neither for $\Sigma$ POPs nor Hg. POPs and $\mathrm{Hg}$ measured in blood (plasma and red blood cells, respectively) can be correlated to levels found in storage organs and also adipose tissues, in birds but also chelonians and humans (Henriksen et al. 1998; Henny et al. 2002; ; Pauwels et al. 2000; Wayland et al. 2001; Keller et al. 2004; van de Merwe et al. 2010; Szumiło et al. 2013; Fromant et al. unpublished data). Thus, blood contaminant concentration may be a good proxy of contaminant burden in other organs.

The relationship between $\mathrm{Hg}$ and age in seabirds is often contradictory, for example liver $\mathrm{Hg}$ was found to decrease, increase or be unrelated to age (Furness and Hutton, 1979; Hutton 1981; Thompson et al. 1991). For blood, the relationship between $\mathrm{Hg}$ contamination and age is also not clear: no relationship was found between age and $\mathrm{Hg}$ contamination (GonzálesSolís et al. 2002; Tavares et al. 2013) but in pre-breeding snow petrels and incubating cape petrels (Daption capense), a negative relationship was found between blood $\mathrm{Hg}$ and age (Tartu et al., unpublished data). This relationship was, however more likely the result of an age-related change in feeding ecology. With regard to POPs, it seems that in seabirds, concentrations in different tissues and blood increase until a steady-state is reached, often before the age of breeding (Donaldson et al. 1997; Newton et al. 1981; van den Brink et al. 1998), and for breeding birds, most studies have not observed any age-related POP accumulation (Bustnes et al. 2003; Newton et al. 1981). In this study, all snow petrels were breeders, and presumably they had already reached their steady-state levels.

Besides, seabirds can biotransform PCBs and eliminate POPs through their preen gland (Borgå et al. 2005; Henriksen et al. 1996; Solheim 2010), in the same line Hg can be excreted 
through feather growth (Bearhop et al. 2000). These mechanisms could partially explain the lack of association between blood contaminants and increasing age. Also we have to remain cautious as we hypothesized that in snow petrels, as in other bird species, blood contaminants would represent levels in internal tissues (Henny et al. 2002; Szumiło et al. 2013; Wayland et al. 2001; Henriksen et al., 1998; Fromant et al. unpublished data). However, we have no evidence for this relationship in snow petrels. Additionally, following food intake or lipid mobilization, contaminant levels in blood may fluctuate more than those in adipose tissues or liver and this could mask a hypothetical contaminant/age relationship.

\section{POPs: Concentrations and relationship with the CORT stress response}

Very few studies have examined blood concentrations of POPs in adult Antarctic seabirds, and among the few studies, comparisons are made difficult due to different analytical methods. Indeed, POPs are often described as a "sum of compounds" and the compounds taken into the sum vary among studies. However, some OCPs are often reported individually since their detrimental effects have been well identified. This is the case of the HCB a relatively volatile compound (Calamari et al. 1991) principally used in fungicide formulations (Barber et al. 2005). Higher concentrations of this compound are commonly found in species restricted to the Antarctic region than those in temperate regions (e.g. van den Brink, 1997). HCB was the OCP with the highest concentrations in incubating snow petrels, but much lower than the concentrations found in other high-Antarctic species such as south polar skuas (Catharacta maccormicki) from Svarthamaren ( $\left.71^{\circ} 53^{\prime} \mathrm{S}, 05^{\circ} 10^{\prime} \mathrm{E}\right)$ in Dronning Maud Land (Antarctica): i.e. HCB concentrations were 10-fold lower, and mirex concentrations 100-fold lower (Bustnes et al. 2006, 2007). These results could be the consequence of a different trophic level, toxicokinetic factors (e.g. metabolism, clearance rate), compound-specific physicochemical properties $\left(\mathrm{K}_{\mathrm{ow}}\right.$, half-life) or depend on the bio-availability of contaminants in the breeding area (Walker et al. 2012). 
The Arctic is more contaminated by POPs than Antarctica (Bustnes et al. 2006; Choi et al. 2008), HCB concentrations in snow petrels were slightly lower than those measured in plasma of incubating black-legged kittiwakes ( versus $2.5 \pm 0.44 \mathrm{ng}_{\bullet} \mathrm{g}^{-1}$ ww respectively (Tartu et al. unpublished data). In comparison, incubating glaucous gulls (Larus hyperboreus) had HCB concentrations in plasma much

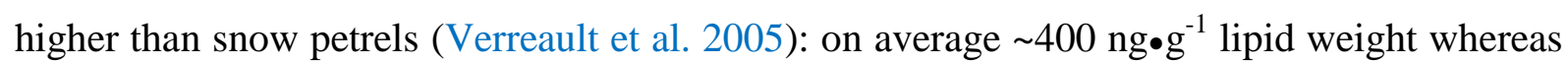
in snow petrels concentrations given in lipid weight average $\sim 200 \mathrm{ng} \bullet \mathrm{g}^{-1}$. In both blacklegged kittiwakes and glaucous gulls there is evidence of CORT disruption by POPs (Nordstad et al. 2012; Verboven et al. 2010). Indeed, in both species increasing POP concentrations were related to higher baseline CORT concentrations and for male glaucous gulls, higher POP concentrations were related to decreasing stress-induced CORT concentrations. In the present study, increasing $\Sigma$ POPs were not related to baseline CORT, but to stress-induced and post-stress CORT concentrations. Hence, the most polluted birds released more CORT when subjected to a handling stress protocol, and those concentrations remained high 20 minutes post-stress. These results are in accordance with the recent finding that POPs, and especially PCBs are associated with a higher adrenocortical response to an acute stress in pre-laying female black-legged kittiwakes (Tartu et al. 2014). However, although post-stress CORT concentrations were admittedly higher in the most contaminated snow petrels they did not decrease more slowly than in less polluted birds, indicating that negative feedback from CORT on the hypothalamus and the pituitary was functional.

One possible explanation for the over-release of CORT could be related to an increase of the number of adreno-corticotrophic-hormone (ACTH) receptors (ACTH-R) on the adrenals. ACTH is one of the few polypeptide hormones having a positive trophic effect on its own receptors (Beuschlein et al. 2001; Penhoat et al. 1989). Thus, an increase of ACTH-R in the most POP contaminated snow petrels may be the consequence of an excess of ACTH input to 
adrenals. This suggests that $\Sigma$ POPs may alter the functioning of the pituitary by stimulating ACTH release and/or that $\Sigma$ POPs may mimic ACTH and bind to ACTH-R, which in that case would mobilize more ACTH-R from the adrenals of the most contaminated individuals. However this study is correlational, we cannot confirm without experimental support that the observed relationship is not the consequence of other intrinsic or extrinsic factors. Yet, an exacerbated secretion of CORT in response to a stressful event often mirrors poor fitness related traits as lowered parental investment (Angelier et al. 2009a; Bókony et al. 2009; Goutte et al. 2011b; Lendvai et al. 2007) or an impacted survival (Blas et al. 2007; Goutte et al. 2010; Romero 2012). Nevertheless we did not find any relationship between POPs and parenting in terms of PRL concentration contrary to the study of Verreault et al. (2008) or egg-neglect behaviour.

\section{Hg: concentrations and relationships with stress-induced PRL and egg neglecting}

Hg concentrations in incubating snow-petrels were within the range of those measured in the

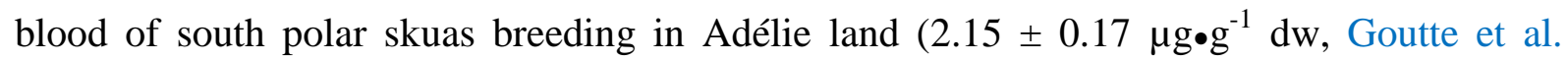
2014). In comparison with an Arctic breeding seabird, we also found comparable concentrations in incubating black-legged kittiwakes, (average $1.6 \pm 0.5 \mu \mathrm{g} \mathrm{g}^{-1} \mathrm{dw}$, Tartu et al. unpublished data). Contrary to other studies on free-ranging birds (Franceschini et al. 2009; Herring et al. 2012; Wada et al. 2009), we did not find any relationship between $\mathrm{Hg}$ and CORT secretion. Hg is well-known for its negative effects on breeding (reviewed in Tan et al. 2009). However, to the best of our knowledge, no studies have described relationships between $\mathrm{Hg}$ and PRL in free-living organisms. In humans, urinary $\mathrm{Hg}$ concentration was negatively correlated to plasma PRL (De Burbure and Bernard 2006; Lucchini et al. 2002, 2003). In the present study, we found a similar relationship in incubating male snow petrels: increasing $\mathrm{Hg}$ concentrations were related to decreasing stress-induced PRL concentrations. 
PRL is an anterior pituitary hormone, and a previous study on polar seabirds has described relationships between $\mathrm{Hg}$ and another anterior pituitary hormone: luteinizing hormone (LH, Tartu et al. 2013, Tartu et al. unpublished data). Hg seemed to disrupt LH secretion via a lack of Gonadotropin-Releasing-Hormone (GnRH) input from the hypothalamus (Tartu et al. 2013). GnRH release is controlled by an area of the hypothalamus called zona incerta (BenJonathan and Hnasko, 2001). Interestingly, this area also participates in the secretion of dopamine, a neuro-transmitter which is the principal antagonist of PRL (reviewed in BenJonathan and Hnasko, 2001). Moreover, it has been well established that organic and inorganic $\mathrm{Hg}$ can stimulate the spontaneous release of dopamine in laboratory rodents (Faro et al. 1997, 2000, 2007; Minnema et al. 1989) but also in wild larvae of a fish (Fundulus heteroclitus, Zhou et al. 1999) and in wild American minks Mustela vison, where Hg induced a decrease of dopaminergic receptors and ligand affinity interpreted as an adaptive mechanism to prevent the hyper-stimulation of the dopaminergic system (Basu et al. 2005). Additionally, when subjected to a stress, dopamine concentrations in blood increase (e.g. Finlay and Zigmond, 1997). Stress-induced dopamine synthesis in male snow petrels may thus be enhanced by $\mathrm{Hg}$ contamination, and result in a decrease of stress-induced PRL concentrations but not baseline or post-stress PRL concentrations. The fact that the most polluted birds quickly decrease their PRL concentrations when exposed to stress may highly affect their parental investment: they would be more likely to neglect their egg than less polluted birds. This goes together with the fact that in males, where PRL concentrations were lower than in females, the most polluted individuals were more likely to neglect their egg. In females, PRL concentrations and egg-neglect behaviour were not related to $\mathrm{Hg}$, maybe their PRL concentrations remained sufficiently high to prevent egg-neglect, a behaviour associated with poor hatching success and chick mortality (Boersma and Wheelwright 1979; Angelier et al. 2007). 


\section{CONCLUSION}

In conclusion, there were no relationships between age and POPs or $\mathrm{Hg}$, which is in line with most other studies. However we report significant relationships between contaminants and hormones involved in reproductive decisions. Over time, the action of POPs and $\mathrm{Hg}$ may jeopardize the maintenance of long-lived species populations. Indeed in long-lived species, that are expected to maximize their own survival rather than that of their brood, an exacerbated stress response as a consequence of POPs contamination and a decrease of PRL for the most $\mathrm{Hg}$ polluted males, are additional threats that may encourage individuals to refrain from breeding or desert their brood. To confirm the reported relationships, this study would greatly benefit from further experimental support.

\section{Role of the funding source}

This project was funded by Agence Nationale de la Recherche (ANR PolarTop, O. Chastel), the French Polar Institute (IPEV, Program 109, H. Weimerskirch) and the 7th research program of the European Community FP7/2007-2013 (Marie-Curie Fellowship, no. 237034, F. Angelier). The funders played no part in the design, analysis, or reporting of the study.

\section{Conflict of interest statement}

The authors declare no conflict of interest.

\section{Acknowledgements}

The authors thank M. Kriloff, S. Lucchini, F. Amélineau, E. Cottin, and A.M. Thierry for their help in the field, C. Trouvé, C. Parenteau, S. Ruault, C. Churlaud, A. Carravieri, L. 
Peluhet and P. van Delft for their assistance in hormone, $\mathrm{Hg}$ and POPs assays and three anonymous referees for their very useful comments on a previous version of the manuscript.

\section{REFERENCES}

Angelier, F., Moe, B., Weimerskirch, H., Chastel, O., 2007. Age-specific reproductive success in a long-lived bird: do older parents resist stress better? Journal of Animal Ecology 76, 1181-1191. doi:10.1111/j.1365-2656.2007.01295.x

Angelier, F., Clément-Chastel, C., Welcker, J., Gabrielsen, G.W., Chastel, O., 2009a. How does corticosterone affect parental behaviour and reproductive success? A study of prolactin in black-legged kittiwakes. Functional Ecology 23, 784-793. doi:10.1111/j.1365-2435.2009.01545.x

Angelier, F., Moe, B., Blanc, S., Chastel, O., 2009b. What Factors Drive Prolactin and Corticosterone Responses to Stress in a Long-Lived Bird Species (Snow Petrel Pagodroma nivea)? Physiological and Biochemical Zoology 82, 590-602. doi:10.1086/592846

Angelier, F., Chastel, O., 2009. Stress, prolactin and parental investment in birds: a review. Gen. Comp. Endocrinol. 163, 142-148. doi:10.1016/j.ygcen.2009.03.028

Angelier, F., Wingfield, J.C., Weimerskirch, H., Chastel, O., 2010. Hormonal correlates of individual quality in a long-lived bird: a test of the "corticosterone-fitness hypothesis". Biol. Lett. 6, 846-849. doi:10.1098/rsbl.2010.0376

Angelier, F., Wingfield, J.C., 2013. Importance of the glucocorticoid stress response in a changing world: Theory, hypotheses and perspectives. General and Comparative Endocrinology, 10th International Symposium on Avian Endocrinology 190, 118-128. doi:10.1016/j.ygcen.2013.05.022

Angelier, F., Wingfield, J.C., Trouvé, C., de Grissac, S., Chastel, O., 2013. Modulation of the prolactin and the corticosterone stress responses: Do they tell the same story in a longlived bird, the Cape petrel? General and Comparative Endocrinology 182, 7-15. doi:10.1016/j.ygcen.2012.10.008

Barber, J.L., Sweetman, A.J., van Wijk, D., Jones, K.C., 2005. Hexachlorobenzene in the global environment: Emissions, levels, distribution, trends and processes. Science of The Total Environment 349, 1-44. doi:10.1016/j.scitotenv.2005.03.014

Barbraud, C., Weimerskirch, H., 2001. Contrasting effects of the extent of sea-ice on the breeding performance of an Antarctic top predator, the Snow Petrel Pagodroma nivea. Journal of Avian Biology 32, 297-302. doi:10.1111/j.0908-8857.2001.320402.x

Bargagli, R., 2008. Environmental contamination in Antarctic ecosystems. Science of The Total Environment 400, 212-226. doi:10.1016/j.scitotenv.2008.06.062

Basu, N., Klenavic, K., Gamberg, M., O’Brien, M., Evans, D., Scheuhammer, A.M., Chan, H.M., 2005. Effects of mercury on neurochemical receptor-binding characteristics in wild mink. Environmental Toxicology and Chemistry 24, 1444-1450. doi:10.1897/04048R.1

Bearhop, S., Ruxton, G.D., Furness, R.W., 2000. Dynamics of mercury in blood and feathers of great skuas. Environmental Toxicology and Chemistry 19, 1638-1643. doi:10.1002/etc.5620190622

Ben-Jonathan, N., Hnasko, R., 2001. Dopamine as a Prolactin (PRL) Inhibitor. Endocrine Reviews 22, 724-763. doi:10.1210/er.22.6.724

Bergman, A., Heindel, J.J., Jobling, S., Kidd, K.A., Zoeller, R.T., 2013. State of the science of endocrine disrupting chemicals 2012: an assessment of the state of the science of 
endocrine disruptors prepared by a group of experts for the United Nations Environment Programme and World Health Organization. Xxv +260 pp.

Beuschlein, F., Fassnacht, M., Klink, A., Allolio, B., Reincke, M., 2001. ACTH-receptor expression, regulation and role in adrenocortial tumor formation. Eur $\mathrm{J}$ Endocrinol 144, 199-206. doi:10.1530/eje.0.1440199

Blas, J., Bortolotti, G.R., Tella, J.L., Baos, R., Marchant, T.A., 2007. Stress response during development predicts fitness in a wild, long lived vertebrate. PNAS 104, 8880-8884. doi:10.1073/pnas.0700232104

Boersma, P.D., Wheelwright, N.T., 1979. Egg neglect in the Procellariiformes: reproductive adaptations in the Fork-tailed Storm-Petrel. Condor 157-165.

Bókony, V., Lendvai, Á.Z., Liker, A., Angelier, F., Wingfield, J.C., Chastel, O., 2009. Stress Response and the Value of Reproduction: Are Birds Prudent Parents? The American Naturalist 173, 589-598. doi:10.1086/593131

Bonier, F., Martin, P.R., Moore, I.T., Wingfield, J.C., 2009. Do baseline glucocorticoids predict fitness? Trends in Ecology \& Evolution 24, 634-642. doi:10.1016/j.tree.2009.04.013

Borgå, K., Wolkers, H., Skaare, J.U., Hop, H., Muir, D.C.G., Gabrielsen, G.W., 2005. Bioaccumulation of PCBs in Arctic seabirds: influence of dietary exposure and congener biotransformation. Environmental Pollution 134, 397-409. doi:10.1016/j.envpol.2004.09.016

Breuner, C.W., Patterson, S.H., Hahn, T.P., 2008. In search of relationships between the acute adrenocortical response and fitness. General and Comparative Endocrinology 157, 288-295. doi:10.1016/j.ygcen.2008.05.017

Buntin, J. D. Parental Care: Evolution, Mechanisms, And Adaptive Significance: Parental Care: Evolution, Mechanisms, And Adaptive Significance; Academic Press, 1996.

Bustamante, P., Lahaye, V., Durnez, C., Churlaud, C., Caurant, F., 2006. Total and organic $\mathrm{Hg}$ concentrations in cephalopods from the North Eastern Atlantic waters: Influence of geographical origin and feeding ecology. Science of The Total Environment 368, 585596. doi:10.1016/j.scitotenv.2006.01.038

Bustnes, J. O., Bakken, V., Erikstad, K. E., Mehlum, F., Skaare, J. U., 2001. Patterns of incubation and nest-site attentiveness in relation to organochlorine (PCB) contamination in glaucous gulls. Journal of Applied Ecology 38, 791-801. doi:10.1046/j.1365-2664.2001.00633.x

Bustnes, J.O., Bakken, V., Skaare, J.U., Erikstad, K.E., 2003. Age and accumulation of persistent organochlorines: A study of arctic-breeding glaucous gulls (Larus hyperboreus). Environmental Toxicology and Chemistry 22, 2173-2179. doi:10.1897/02-456

Bustnes, J.O., Tveraa, T., Henden, J.A., Varpe, Ø., Janssen, K., Skaare, J.U., 2006. Organochlorines in Antarctic and Arctic Avian Top Predators: A Comparison between the South Polar Skua and Two Species of Northern Hemisphere Gulls. Environ. Sci. Technol. 40, 2826-2831. doi:10.1021/es051920q

Bustnes, J.O., Tveraa, T., Varpe, Ø., Henden, J.A., Skaare, J.U., 2007. Reproductive performance and organochlorine pollutants in an Antarctic marine top predator: The south polar skua. Environment International 33, 911-918. doi:10.1016/j.envint.2007.04.010

Calamari, D., Bacci, E., Focardi, S., Gaggi, C., Morosini, M., Vighi, M., 1991. Role of plant biomass in the global environmental partitioning of chlorinated hydrocarbons. Environ. Sci. Technol. 25, 1489-1495. doi:10.1021/es00020a020 
Chastel, O., Weimerskirch, H., Jouventin, P., 1993. High annual variability in reproductive success and survival of an Antarctic seabird, the snow petrel Pagodroma nivea. Oecologia 94, 278-285. doi:10.1007/BF00341328

Chastel, O., Lacroix, A., Weimerskirch, H., Gabrielsen, G.W., 2005. Modulation of prolactin but not corticosterone responses to stress in relation to parental effort in a long-lived bird. Hormones and Behavior 47, 459-466. doi:10.1016/j.yhbeh.2004.10.009

Chaurand, T., Weimerskirch, H., 1994. Incubation routine, body mass regulation and egg neglect in the blue petrel Halobaena caerulea. Ibis 136, 285-290.

Cherel, Y., Mauget, R., Lacroix, A., Gilles, J., 1994. Seasonal and fasting-related changes in circulating gonadal steroids and prolactin in king penguins, Aptenodytes patagonicus. Physiological Zoology 67, 1154-1154.

Choi, S.-D., Baek, S.-Y., Chang, Y.-S., Wania, F., Ikonomou, M.G., Yoon, Y.-J., Park, B.-K., Hong, S., 2008. Passive Air Sampling of Polychlorinated Biphenyls and Organochlorine Pesticides at the Korean Arctic and Antarctic Research Stations: Implications for Long-Range Transport and Local Pollution. Environ. Sci. Technol. 42, 7125-7131. doi:10.1021/es801004p

Clarke, A., Harris, C.M., 2003. Polar marine ecosystems: major threats and future change. Environmental Conservation 30, 1-25. doi:10.1017/S0376892903000018

Corsolini, S., Borghesi, N., Ademollo, N., Focardi, S., 2011. Chlorinated biphenyls and pesticides in migrating and resident seabirds from East and West Antarctica. Environment international 37, 1329-1335.

Criscuolo, F., Chastel, O., Bertile, F., Gabrielsen, G.W., Maho, Y.L., Raclot, T., 2005. Corticosterone alone does not trigger a short term behavioural shift in incubating female common eiders Somateria mollissima, but does modify long term reproductive success. Journal of Avian Biology 36, 306-312. doi:10.1111/j.09088857.2005.03371.x

De Burbure, C., Bernard, A., 2006. Prolactin Changes as a Consequence of Chemical Exposure: de Burbure and Bernard Respond. Environ Health Perspect 114, A574.

Donaldson, G.M., Braune, B.M., Gaston, A.J., Noble, D.G., 1997a. Organochlorine and Heavy Metal Residues in Breast Muscle of Known-Age Thick-Milled Murres (Uria lomvia) from the Canadian Arctic. Arch. Environ. Contam. Toxicol. 33, 430-435. doi:10.1007/s002449900273

Faro, L.R.F., Durán, R., do Nascimento, J.L.M., Alfonso, M., Picanço-Diniz, C.W., 1997. Effects of Methyl Mercury on the in Vivo Release of Dopamine and Its Acidic Metabolites DOPAC and HVA from Striatum of Rats. Ecotoxicology and Environmental Safety 38, 95-98. doi:10.1006/eesa.1997.1567

Faro, L.R.F., Nascimento, J.L.M. do, José, J.M.S., Alfonso, M., Durán, R., 2000. Intrastriatal Administration of Methylmercury Increases In Vivo Dopamine Release. Neurochem Res 25, 225-229. doi:10.1023/A:1007571403413

Faro, L.R.F., Rodrigues, K.J.A., Santana, M.B., Vidal, L., Alfonso, M., Durán, R., 2007. Comparative effects of organic and inorganic mercury on in vivo dopamine release in freely moving rats. Brazilian Journal of Medical and Biological Research 40, 13611365. doi:10.1590/S0100-879X2006005000157

Finlay, J.M., Zigmond, M.J., 1997. The Effects of Stress on Central Dopaminergic Neurons: Possible Clinical Implications. Neurochem Res 22, 1387-1394. doi:10.1023/A:1022075324164

Franceschini, M.D., Lane, O.P., Evers, D.C., Reed, J.M., Hoskins, B., Romero, L.M., 2009. The corticosterone stress response and mercury contamination in free-living tree swallows, Tachycineta bicolor. Ecotoxicology 18, 514-521. doi:10.1007/s10646-0090309-2 
Frings, C.S., Fendley, T.W., Dunn, R.T., Queen, C.A., 1972. Improved Determination of Total Serum Lipids by the Sulfo-Phospho-Vanillin Reaction. Clinical Chemistry 18, 673-674.

Furness, R., Hutton, M., 1979. Pollutant levels in the great skua Catharacta skua. Environmental Pollution (1970) 19, 261-268. doi:10.1016/0013-9327(79)90118-6

Gabrielsen, G.W., 2007. Levels and effects of persistent organic pollutants in arctic animals, in: Ørbæk, D.J.B., Kallenborn, D.R., Tombre, D.I., Hegseth, D.E.N., Falk-Petersen, D.S., Hoel, D.A.H. (Eds.), Arctic Alpine Ecosystems and People in a Changing Environment. Springer Berlin Heidelberg, pp. 377-412.

Gonzáles-Solís, J., Sanpera, C., Ruiz, X., 2002. Metals and selenium as bioindicators of geographic and trophic segregation in giant petrels Macronectes spp. Mar Ecol Prog Ser 244, 257-264. doi:10.3354/meps 244257

Gordeev, V., 2002. Pollution of the Arctic. Reg Environ Change 3, 88-98. doi:10.1007/s10113-002-0041-4

Goutte, A., Angelier, F., Welcker, J., Moe, B., Clément-Chastel, C., Gabrielsen, G.W., Bech, C., Chastel, O., 2010. Long-term survival effect of corticosterone manipulation in Black-legged kittiwakes. General and Comparative Endocrinology 167, 246-251. doi:10.1016/j.ygcen.2010.03.018

Goutte, A., Kriloff, M., Weimerskirch, H., Chastel, O., 2011a. Why do some adult birds skip breeding? A hormonal investigation in a long-lived bird. Biol. Lett. 7, 790-792. doi:10.1098/rsbl.2011.0196

Goutte, A., Antoine, É., Chastel, O., 2011b. Experimentally delayed hatching triggers a magnified stress response in a long-lived bird. Hormones and Behavior 59, 167-173. doi:10.1016/j.yhbeh.2010.11.004

Goutte, A., Clément-Chastel, C., Moe, B., Bech, C., Gabrielsen, G.W., Chastel, O., 2011c. Experimentally reduced corticosterone release promotes early breeding in blacklegged kittiwakes. J Exp Biol 214, 2005-2013. doi:10.1242/jeb.051979

Goutte, A., Chevreuil, M., Alliot, F., Chastel, O., Cherel, Y., Eléaume, M., Massé, G., 2013. Persistent organic pollutants in benthic and pelagic organisms off Adélie Land, Antarctica. Marine pollution bulletin 77, 82-89.

Goutte, A., Bustamante, P., Barbraud, C., Delord, K., Weimerskirch, H., Chastel, O., 2014. Demographic responses to mercury exposure in two closely-related Antarctic top predators. Ecology. doi:10.1890/13-1229.1

Groscolas, R., Lacroix, A., Robin, J.-P., 2008. Spontaneous egg or chick abandonment in energy-depleted king penguins: A role for corticosterone and prolactin? Hormones and Behavior 53, 51-60. doi:10.1016/j.yhbeh.2007.08.010

Guillette, L.J., Gunderson, M.P., 2001. Alterations in development of reproductive and endocrine systems of wildlife populations exposed to endocrine-disrupting contaminants. Reproduction 122, 857-864. doi:10.1530/rep.0.1220857

Heidinger, B.J., Chastel, O., Nisbet, I.C.T., Ketterson, E.D., 2010. Mellowing with age: older parents are less responsive to a stressor in a long-lived seabird. Functional Ecology 24, 1037-1044. doi:10.1111/j.1365-2435.2010.01733.x

Henny, C.J., Hill, E.F., Hoffman, D.J., Spalding, M.G., Grove, R.A., 2002. Nineteenth Century Mercury: Hazard to Wading Birds and Cormorants of the Carson River, Nevada. Ecotoxicology 11, 213-231. doi:10.1023/A:1016327602656

Henriksen, E.O., Gabrielsen, G.W., Skaare, J.U., 1996. Levels and congener pattern of polychlorinated biphenyls in kittiwakes (Rissa tridactyla), in relation to mobilization of body-lipids associated with reproduction. Environmental Pollution 92, 27-37. doi:10.1016/0269-7491(95)00087-9 
Henriksen, E.O., Gabrielsen, G.W., Utne Skaare, J., 1998. Validation of the use of blood samples to assess tissue concentrations of organochlorines in glaucous gulls, Larus hyperboreus. Chemosphere 37, 2627-2643. doi:10.1016/S0045-6535(98)00162-3

Herring, G., Ackerman, J.T., Herzog, M.P., 2012. Mercury Exposure May Suppress Baseline Corticosterone Levels in Juvenile Birds. Environ. Sci. Technol. 46, 6339-6346. doi:10.1021/es300668c

Hutton, M., 1981. Accumulation of heavy metals and selenium in three seabird species from the United Kingdom. Environmental Pollution Series A, Ecological and Biological 26, 129-145. doi:10.1016/0143-1471(81)90043-X

Jenssen, B.M., 2005. Endocrine-Disrupting Chemicals and Climate Change: A Worst-Case Combination for Arctic Marine Mammals and Seabirds? Environmental Health Perspectives 114, 76-80. doi:10.1289/ehp.8057

Keller, J.M., Kucklick, J.R., Harms, C.A., McClellan-Green, P.D., 2004. Organochlorine contaminants in sea turtles: Correlations between whole blood and fat. Environmental Toxicology and Chemistry 23, 726-738. doi:10.1897/03-254

Kitaysky, A.S., Wingfield, J.C., Piatt, J.F., 1999. Dynamics of food availability, body condition and physiological stress response in breeding Black-legged Kittiwakes. Functional Ecology 13, 577-584. doi:10.1046/j.1365-2435.1999.00352.x

Koch, K.A., Wingfield, J.C., Buntin, J.D., 2004. Prolactin-induced parental hyperphagia in ring doves: are glucocorticoids involved? Hormones and Behavior 46, 498-505. doi:10.1016/j.yhbeh.2004.02.012

Lendvai, Á.Z., Giraudeau, M., Chastel, O., 2007. Reproduction and modulation of the stress response: an experimental test in the house sparrow. Proc. R. Soc. B 274, 391-397. doi:10.1098/rspb.2006.3735

Lormée, H., Jouventin, P., Trouve, C., Chastel, O., 2003. Sex-specific patterns in baseline corticosterone and body condition changes in breeding Red-footed Boobies Sula sula. Ibis 145, 212-219. doi:10.1046/j.1474-919X.2003.00106.x

Love, O.P., Shutt, L.J., Silfies, J.S., Bortolotti, G.R., Smits, J.E.G., Bird, D.M., 2003. Effects of Dietary PCB Exposure on Adrenocortical Function in Captive American Kestrels (Falco sparverius). Ecotoxicology 12, 199-208. doi:10.1023/A:1022502826800

Lucchini, R., Cortesi, I., Facco, P., Benedetti, L., Camerino, D., Carta, P., Urbano, M.L., Zaccheo, A., Alessio, L., 2002. Neurotoxic effect of exposure to low doses of mercury. Med Lav 93, 202-214.

Lucchini, R., Calza, S., Camerino, D., Carta, P., Decarli, A., Parrinello, G., Soleo, L., Zefferino, R., Alessio, L., 2003. Application of a Latent Variable Model for a Multicenter Study on Early Effects Due to Mercury Exposure. NeuroToxicology 24, 605-616. doi:10.1016/S0161-813X(03)00048-2

Minnema, D.J., Cooper, G.P., Greenland, R.D., 1989. Effects of methylmercury on neurotransmitter release from rat brain synaptosomes. Toxicology and Applied Pharmacology 99, 510-521. doi:10.1016/0041-008X(89)90158-0

Moline, M.A., Karnovsky, N.J., Brown, Z., Divoky, G.J., Frazer, T.K., Jacoby, C.A., Torres, J.J., Fraser, W.R., 2008. High Latitude Changes in Ice Dynamics and Their Impact on Polar Marine Ecosystems. Annals of the New York Academy of Sciences 1134, 267319. doi:10.1196/annals.1439.010

Newton, I., Bogan, J., Marquiss, M., 1981. Organochlorine contamination and age in sparrowhawks. Environmental Pollution Series A, Ecological and Biological 25, 155160. doi:10.1016/0143-1471(81)90016-7

Noël, M., Barrett-Lennard, L., Guinet, C., Dangerfield, N., Ross, P.S., 2009. Persistent organic pollutants (POPs) in killer whales (Orcinus orca) from the Crozet Archipelago, 
southern Indian Ocean. Marine Environmental Research 68, 196-202. doi:10.1016/j.marenvres.2009.06.009

Nordstad, T., Moe, B., Bustnes, J.O., Bech, C., Chastel, O., Goutte, A., Sagerup, K., Trouvé, C., Herzke, D., Gabrielsen, G.W., 2012. Relationships between POPs and baseline corticosterone levels in black-legged kittiwakes (Rissa tridactyla) across their breeding cycle. Environmental Pollution 164, 219-226. doi:10.1016/j.envpol.2012.01.044

Odermatt, A., Gumy, C., 2008. Glucocorticoid and mineralocorticoid action: Why should we consider influences by environmental chemicals? Biochemical Pharmacology 76, 1184-1193. doi:10.1016/j.bcp.2008.07.019

Ottinger, M.A., Abdelnabi, M., Quinn, M., Golden, N., Wu, J., Thompson, N., 2002. Reproductive consequences of EDCs in birds: What do laboratory effects mean in field species? Neurotoxicology and Teratology 24, 17-28. doi:10.1016/S08920362(01)00195-7

Ottinger, M.A., Carro, T., Bohannon, M., Baltos, L., Marcell, A.M., McKernan, M., Dean, K.M., Lavoie, E., Abdelnabi, M., 2013. Assessing effects of environmental chemicals on neuroendocrine systems: potential mechanisms and functional outcomes. Gen. Comp. Endocrinol. 190, 194-202. doi:10.1016/j.ygcen.2013.06.004

Pauwels, A., Covaci, A., Weyler, J., Delbeke, L., Dhont, M., Sutter, P.D., D’Hooghe, T., Schepens, P.J.C., 2000. Comparison of Persistent Organic Pollutant Residues in Serum and Adipose Tissue in a Female Population in Belgium, 1996-1998. Arch. Environ. Contam. Toxicol. 39, 265-270. doi:10.1007/s002440010104

Penhoat, A., Jaillard, C., Saez, J.M., 1989. Corticotropin positively regulates its own receptors and cAMP response in cultured bovine adrenal cells. PNAS 86, 4978-4981.

Ricklefs, R.E., Wikelski, M., 2002. The physiology/life-history nexus. Trends in Ecology \& Evolution 17, 462-468. doi:10.1016/S0169-5347(02)02578-8

Risebrough, R.W., De Lappe, B.W., Schmidt, T.T., 1976. Bioaccumulation factors of chlorinated hydrocarbons between mussels and seawater. Marine Pollution Bulletin 7, 225-228. doi:10.1016/0025-326X(76)90266-6

Romero, L.M., Reed, J.M., 2005. Collecting baseline corticosterone samples in the field: is under 3 min good enough? Comparative Biochemistry and Physiology Part A: Molecular \& Integrative Physiology 140, 73-79. doi:10.1016/j.cbpb.2004.11.004

Romero, L.M., 2012. Using the reactive scope model to understand why stress physiology predicts survival during starvation in Galápagos marine iguanas. General and Comparative Endocrinology 176, 296-299. doi:10.1016/j.ygcen.2011.11.004

Rowe, C.L., 2008. "The Calamity of So Long Life": Life Histories, Contaminants, and Potential Emerging Threats to Long-lived Vertebrates. BioScience 58, 623-631. doi:10.1641/B580709

Ryan, P.G., Watkins, B.P., 1989. Snow Petrel Breeding Biology at an Inland Site in Continental Antarctica. Colonial Waterbirds 12, 176. doi:10.2307/1521338

Smetacek, V., Nicol, S., 2005. Polar ocean ecosystems in a changing world. Nature 437, 362368. doi:10.1038/nature04161

Solheim, S.A., 2010. The Preen Gland - an Organ for Excretion of Persistent Organic Pollutants in Black-legged Kittiwake (Rissa tridactyla). Master thesis. University of Bergen

Szumiło, E., Szubska, M., Meissner, W., Bełdowska, M., Falkowska, L., 2013. Mercury in immature and adults Herring Gulls (Larus argentatus) wintering on the Gulf of Gdańsk area. Ocean and Hydro 42, 260-267. doi:10.2478/s13545-013-0082-y

Tan, S.W., Meiller, J.C., Mahaffey, K.R., 2009. The endocrine effects of mercury in humans and wildlife. Critical Reviews in Toxicology 39, 228-269. doi:10.1080/10408440802233259 
Tapie, N., Menach, K.L., Pasquaud, S., Elie, P., Devier, M.H., Budzinski, H., 2011. PBDE and PCB contamination of eels from the Gironde estuary: From glass eels to silver eels. Chemosphere 83, 175-185. doi:10.1016/j.chemosphere.2010.12.044

Tartu, S., Goutte, A., Bustamante, P., Angelier, F., Moe, B., Clément-Chastel, C., Bech, C., Gabrielsen, G.W., Bustnes, J.O., Chastel, O., 2013. To breed or not to breed: endocrine response to mercury contamination by an Arctic seabird. Biol. Lett. 9, 20130317. doi:10.1098/rsbl.2013.0317

Tartu, S., Angelier, F., Herzke, D., Moe, B., Bech, C., Gabrielsen, G.W., Bustnes, J.O., Chastel, O., 2014. The stress of being contaminated? Adrenocortical function and reproduction in relation to persistent organic pollutants in female black legged kittiwakes. Science of The Total Environment 476-477, 553-560. doi:10.1016/j.scitotenv.2014.01.060

Tavares, S., Xavier, J.C., Phillips, R.A., Pereira, M.E., Pardal, M.A., 2013. Influence of age, sex and breeding status on mercury accumulation patterns in the wandering albatross Diomedea exulans. Environmental Pollution 181, 315-320. doi:10.1016/j.envpol.2013.06.032

Thompson, D.R., Hamer, K.C., Furness, R.W., n.d. Mercury accumulation in great shuas Catharacta skua of known age and sex, and its effects upon breeding and survival. Journal of applied ecology 28, 672-684.

Tyler, C.R., Jobling, S., Sumpter, J.P., 1998. Endocrine Disruption in Wildlife: A Critical Review of the Evidence. Critical Reviews in Toxicology 28, 319-361. doi:10.1080/10408449891344236

Van de Merwe, J.P., Hodge, M., Olszowy, H.A., Whittier, J.M., Lee, S.Y., 2010. Using blood samples to estimate persistent organic pollutants and metals in green sea turtles $(<\mathrm{i}>$ Chelonia mydas). Marine pollution bulletin 60, 579-588.

Van den Brink, N.W., van Franeker, J.A., de Ruiter-Dijkman, E.M., 1998. Fluctuating concentrations of organochlorine pollutants during a breeding season in two Antarctic seabirds: Adelie penguin and southern fulmar. Environmental Toxicology and Chemistry 17, 702-709. doi:10.1002/etc.5620170426

Van den Brink, N.W., 1997. Directed transport of volatile organochlorine pollutants to polar regions: the effect on the contamination pattern of Antarctic seabirds. Science of The Total Environment 198, 43-50. doi:10.1016/S0048-9697(97)05440-5

Verboven, N., Verreault, J., Letcher, R.J., Gabrielsen, G.W., Evans, N.P., 2009. Nest temperature and parental behaviour of Arctic-breeding glaucous gulls exposed to persistent organic pollutants. Animal Behaviour 77, 411-418. doi:10.1016/j.anbehav.2008.10.022

Verboven, N., Verreault, J., Letcher, R.J., Gabrielsen, G.W., Evans, N.P., 2010. Adrenocortical function of Arctic-breeding glaucous gulls in relation to persistent organic pollutants. General and Comparative Endocrinology 166, 25-32. doi:10.1016/j.ygcen.2009.11.013

Verreault, J., Letcher, R.J., Muir, D.C.G., Chu, S., Gebbink, W.A., Gabrielsen, G.W., 2005. New organochlorine contaminants and metabolites in plasma and eggs of glaucous gulls (larus hyperboreus) from the norwegian arctic. Environmental Toxicology and Chemistry 24, 2486. doi:10.1897/05-067R.1

Verreault, J., Verboven, N., Gabrielsen, G.W., Letcher, R.J., Chastel, O., 2008. Changes in prolactin in a highly organohalogen contaminated Arctic top predator seabird, the glaucous gull. General and Comparative Endocrinology 156, 569-576. doi:10.1016/j.ygcen.2008.02.013 
Wada, H., Cristol, D.A., McNabb, F.M.A., Hopkins, W.A., 2009. Suppressed Adrenocortical Responses and Thyroid Hormone Levels in Birds near a Mercury-Contaminated River. Environ. Sci. Technol. 43, 6031-6038. doi:10.1021/es803707f

Walker, C.H., Sibly, R.M., Hopkin, S.P., Peakall, D.B., 2012. Principles of Ecotoxicology, Fourth Edition. CRC Press.

Wania, F., MacKay, D., 1996. Peer Reviewed: Tracking the Distribution of Persistent Organic Pollutants. Environ. Sci. Technol. 30, 390A-396A. doi:10.1021/es962399q

Wania, F., 2003. Assessing the Potential of Persistent Organic Chemicals for Long-Range Transport and Accumulation in Polar Regions. Environ. Sci. Technol. 37, 1344-1351. doi:10.1021/es026019e

Wayland, M., Garcia-Fernandez, A.J., Neugebauer, E., Gilchrist, H.G., 2001. Concentrations of Cadmium, Mercury and Selenium in Blood, Liver and Kidney of Common Eider Ducks from the Canadian Arctic. Environ Monit Assess 71, 255-267. doi:10.1023/A:1011850000360

Weimerskirch, H., Lallemand, J., Martin, J., 2005. Population sex ratio variation in a monogamous long-lived bird, the wandering albatross. Journal of Animal Ecology 74, 285-291. doi:10.1111/j.1365-2656.2005.00922.x

Wingfield, J., 1994. Modulation of the adrenocortical response to stress in birds. Perspectives in comparative endocrinology 520-528.

Wingfield, J.C., Sapolsky, R.M., 2003. Reproduction and Resistance to Stress: When and How. Journal of Neuroendocrinology 15, 711-724. doi:10.1046/j.13652826.2003.01033.x

Wingfield, J.C. 2013. Ecological processes and the ecology of stress: the impacts of abiotic environmental factors. Functional Ecology 27, 37-44. doi:10.1111/1365-2435.12039

Xie, Z., Zhang, P., Sun, L., Xu, S., Huang, Y., He, W., 2008. Microanalysis of metals in barbs of a snow petrel (Pagodroma Nivea) from the Antarctica using synchrotron radiation X-ray fluorescence. Marine Pollution Bulletin 56, 516-524. doi:10.1016/j.marpolbul.2007.11.015

Zhou, T., Rademacher, D.J., Steinpreis, R.E., Weis, J.S. Neurotransmitter levels in two populations of larval Fundulus heteroclitus after methylmercury exposure. Comparative Biochemistry and Physiology Part C: Pharmacology, Toxicology and Endocrinology 1999 (124), 287-294. doi:10.1016/S0742-8413(99)00077-8 


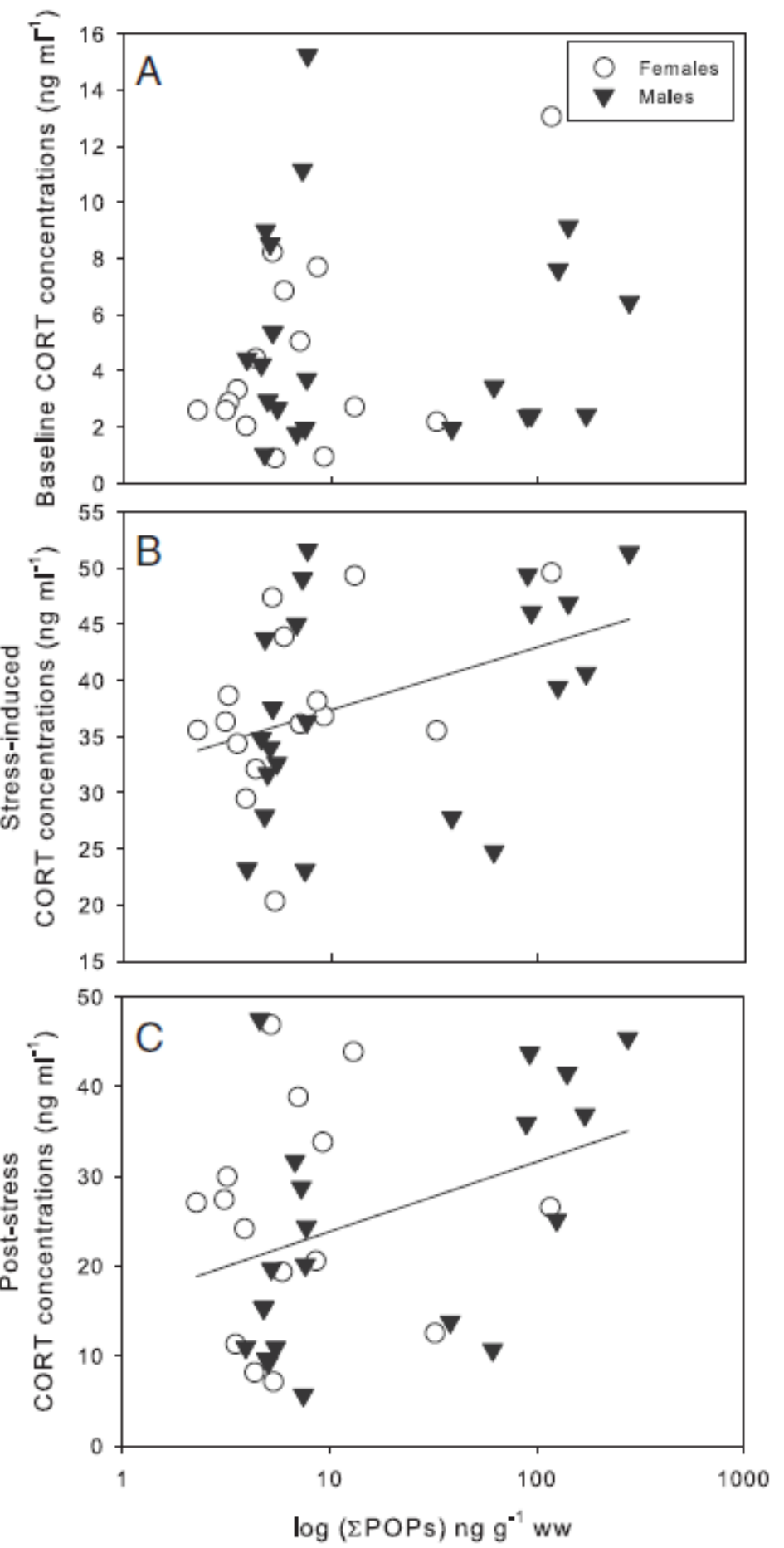

Figure 1: Relationships between plasma $\Sigma$ POP concentrations (ng・ ${ }^{-1}$ wet weight) and plasma CORT concentrations $\left(\mathrm{ng} \cdot \mathrm{ml}^{-1}\right)$ in incubating snow-petrels (A) baseline, (B) stressinduced and (C) post-stress. White circles denote females and black triangles denote males. The solid line refers to statistically significant linear regression. 


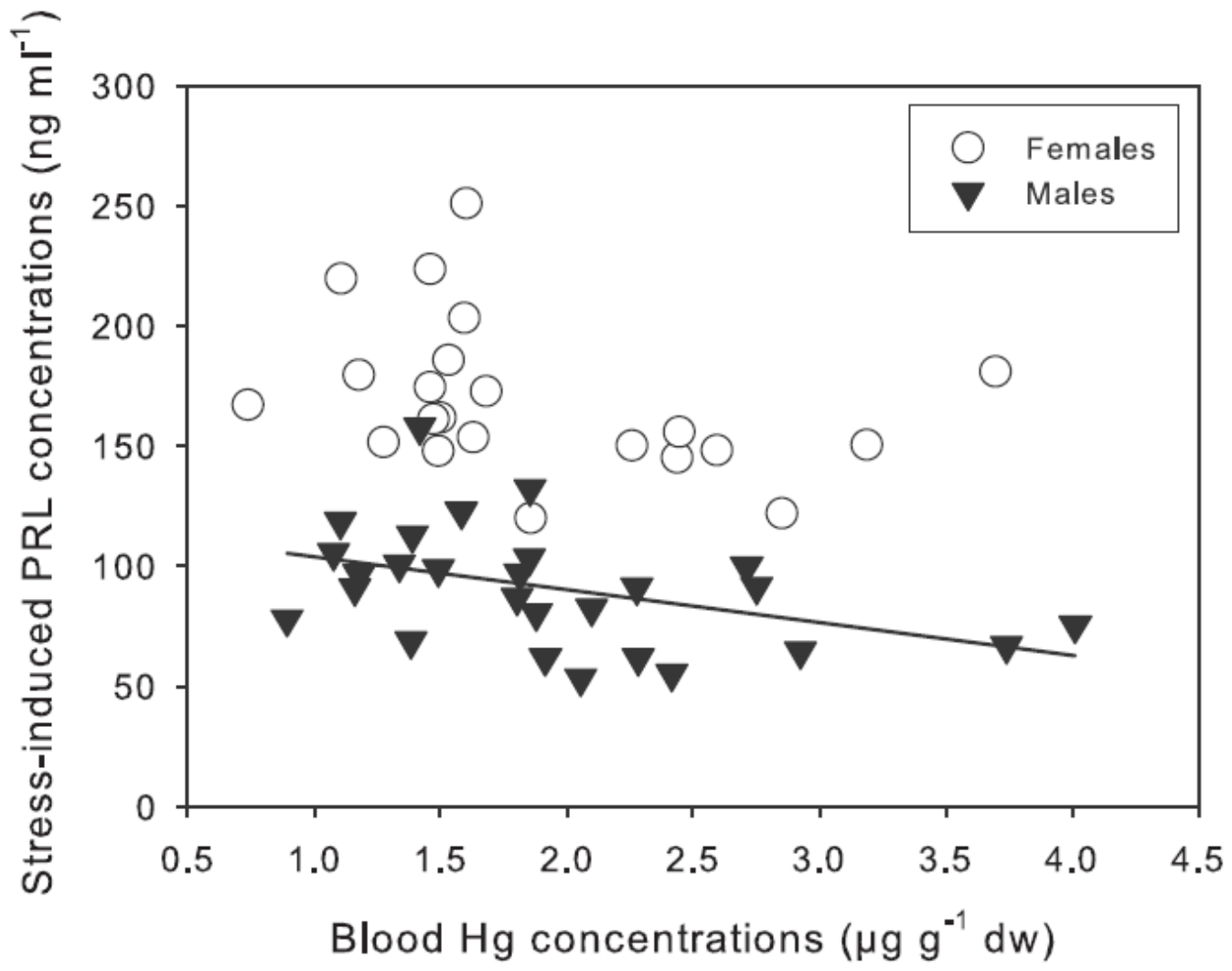

Figure 2: Relationship between total blood $\mathrm{Hg}\left(\mu \mathrm{g} \bullet \mathrm{g}^{-1}\right.$ dry weight $)$ and stress-induced plasma PRL concentrations $\left(\mathrm{ng} \bullet \mathrm{ml}^{-1}\right)$ in incubating snow-petrels. White circles denote females and black triangles denote males. The solid line refers to statistically significant linear regression for males. 


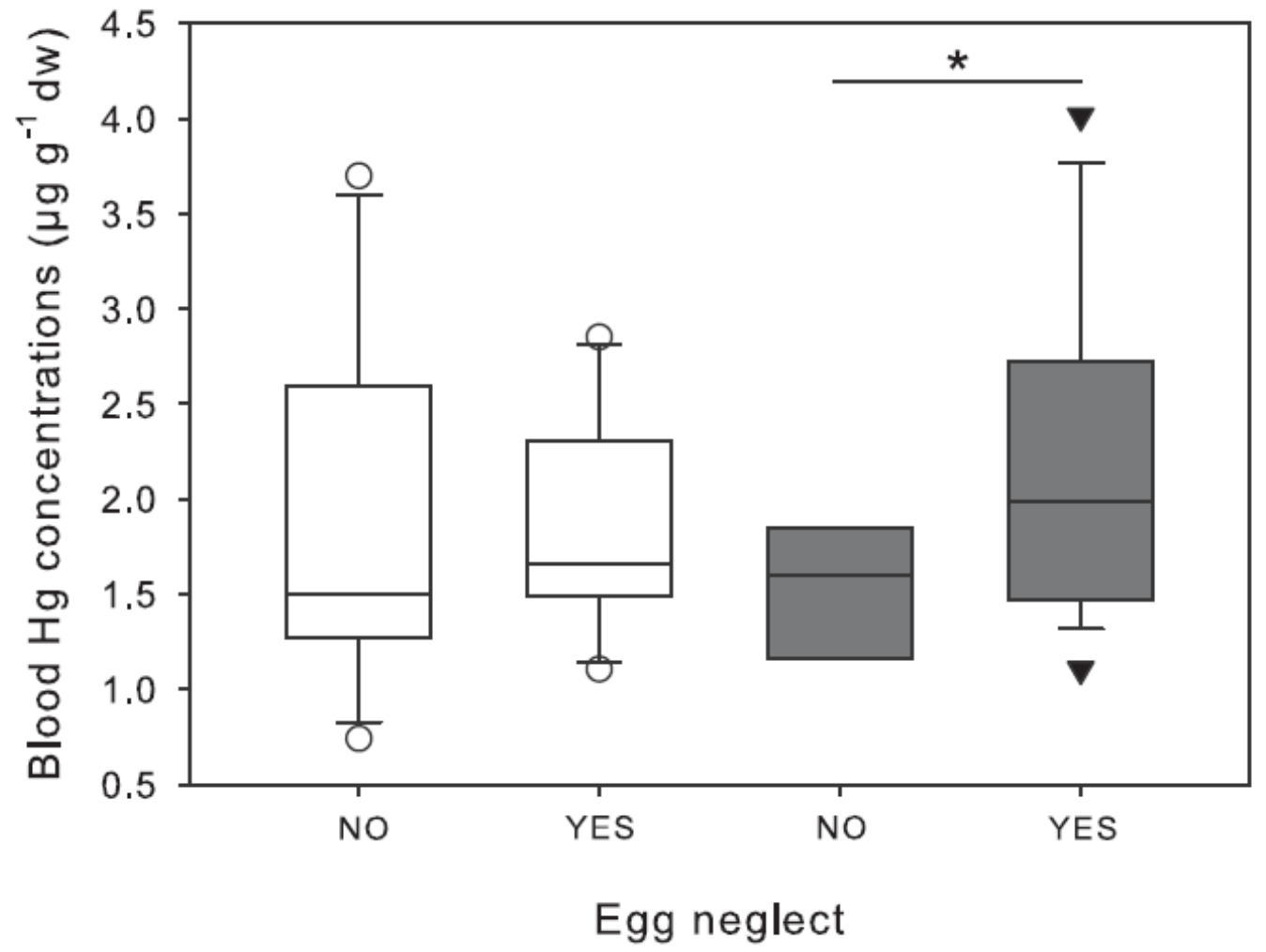

Figure 3: Relationship between blood $\mathrm{Hg}\left(\mu \mathrm{g} \bullet \mathrm{g}^{-1}\right.$ dry weight $)$ and egg-neglect behaviour in incubating snow-petrels. The empty boxes denote females and the filled boxes denote males $(*: \mathrm{p}<0.02)$ 
Table 1: Concentrations of plasma persistent organic pollutants and blood $\mathrm{Hg}\left(\mu \mathrm{g} \bullet \mathrm{g}^{-1}\right)$ of incubating female and male snow petrels. For POPs, concentrations are given in wet-weight $\left(\mathrm{ng} \bullet \mathrm{g}^{-1} \mathrm{Ww}\right)$ in the first rows and lipid-weight $\left(\mathrm{ng} \bullet \mathrm{g}^{-1} \mathrm{lw}\right)$ in the second rows.

\begin{tabular}{|c|c|c|c|c|c|c|}
\hline & \multicolumn{3}{|c|}{ Females } & \multicolumn{3}{|c|}{ Males } \\
\hline & Mean & Standard deviation & Range (min-max) & Mean & Standard deviation & Range (min-max) \\
\hline Lipids (\%) & 0.68 & 0.1 & $(0.48-0.88)$ & 0.7 & 0.1 & $(0.50-0.94)$ \\
\hline \multirow[t]{2}{*}{ CB-50/28 } & 0.4 & 0.6 & $(<0.10-2.1)$ & 1.2 & 2.5 & $(<0.10-10.9)$ \\
\hline & 65.2 & 92.1 & $(<14.4-322.7)$ & 152.2 & 286.7 & $(<14.4-1160.8)$ \\
\hline \multirow[t]{2}{*}{ CB-52 } & 3.8 & 9.5 & $(<0.04-36.6)$ & 10.0 & 16.3 & $(<0.04-63.1)$ \\
\hline & 617.1 & 1494.2 & $(<5.2-5719.4)$ & 1300.2 & 1953.0 & $(<5.2-6709.3)$ \\
\hline \multirow[t]{2}{*}{ CB-101 } & 6.9 & 14.4 & $(<0.02-57.4)$ & 24.0 & 40.5 & $(<0.02-167.9)$ \\
\hline & 1082.1 & 2251.5 & $(<3.1-8976.5)$ & 3151.6 & 5019 & $(<3.1-20730.2)$ \\
\hline \multirow[t]{2}{*}{ CB-118 } & 6.6 & 19.0 & $(<0.04-73.9)$ & 22.7 & 38.4 & $(<0.04-150.6)$ \\
\hline & 1045 & 2960.4 & $(<5.4-11543.5)$ & 2963.4 & 4802.2 & $(<5.4-18587.5)$ \\
\hline \multirow[t]{2}{*}{ CB-138 } & 2.8 & 6.8 & $(<0.02-26.5)$ & 12.1 & 17.5 & $(<0.02-52.4)$ \\
\hline & 441.5 & 1067 & $(<2.5-4136.9)$ & 1601.4 & 2261.5 & $(<2.5-6469.2)$ \\
\hline \multirow{2}{*}{ CB-153 } & 2.6 & 6.3 & $(<0.04-24.6)$ & 9.8 & 13.9 & $(<0.04-44.5)$ \\
\hline & 414.9 & 988.0 & $(<6.0-3845.6)$ & 1297.4 & 1780.2 & $(<6.0-5488.8)$ \\
\hline \multirow[t]{2}{*}{ CB-180 } & 0.2 & 0.6 & $(<0.02-2.2)$ & 1.1 & 1.6 & $(<0.02-5.4)$ \\
\hline & 37 & 88.4 & $(<3.2-338.8)$ & 145.8 & 204.3 & $(<3.2-666.0)$ \\
\hline \multirow[t]{2}{*}{$\Sigma \mathrm{PCBs}^{*}$} & 12.6 & 28.0 & $(1.6-110.7)$ & 47.0 & 72.0 & $(1.8-270.2)$ \\
\hline & 1975.5 & 4379.2 & $(211.4-17297.8)$ & 5394.6 & 8427 & $(222.2-33354.2)$ \\
\hline \multirow[t]{2}{*}{$\mathrm{HCB}$} & 1.3 & 1.0 & $(<0.01-3.2)$ & 2.2 & 1.6 & $(<0.01-4.8)$ \\
\hline & 192.6 & 153.2 & $(<1.2-395.0)$ & 296.6 & 223.9 & $(<1.2-779.1)$ \\
\hline \multirow[t]{2}{*}{ gamma $\mathrm{HCH}$} & 0.1 & 0.1 & $(<0.02-0.3)$ & 0.2 & 0.1 & $(<0.02-0.5)$ \\
\hline & 16.9 & 19.8 & $(<2.1-47.8)$ & 21.7 & 16.8 & $(<2.1-56.5)$ \\
\hline \multirow[t]{2}{*}{ 4,4'-DDE } & 0.6 & 1.0 & $(<0.01-4.0)$ & 0.4 & 0.4 & $(<0.01-1.2)$ \\
\hline & 92.7 & 168 & $(<1.7-669.3)$ & 53.9 & 51.9 & $(<1.7-192.3)$ \\
\hline \multirow[t]{2}{*}{ 4,4'-DDD } & 0.1 & 0.1 & $(<0.05-0.4)$ & 0.1 & 0.2 & $(<0.05-0.9)$ \\
\hline & 8.9 & 17.5 & $(<7.3-65.7)$ & 18.2 & 27.9 & $(<7.3-114.7)$ \\
\hline \multirow[t]{2}{*}{ 2,4'-DDT } & 0.3 & 0.7 & $(<0.03-2.8)$ & 1.1 & 1.9 & $(<0.03-6.6)$ \\
\hline & 47.4 & 114.9 & $(<4.6-433.5)$ & 155.9 & 266.8 & $(<4.6-1018.7)$ \\
\hline \multirow[t]{2}{*}{ 4,4'-DDT } & 0.3 & 0.6 & $(<0.02-2.2)$ & 1.3 & 2.5 & $(<0.02-9.0)$ \\
\hline & 40.2 & 92.0 & $(<2.7-337.2)$ & 176.3 & 350.8 & $(<2.7-1388.9)$ \\
\hline \multirow[t]{2}{*}{ Mirex } & 0.2 & 0.3 & $(<0.02-1.2)$ & 0.6 & 1.0 & $(<0.02-3.4)$ \\
\hline & 26.8 & 49.3 & $(<2.6-190.4)$ & 78.1 & 124.2 & $(<2.6-420.5)$ \\
\hline \multirow[t]{2}{*}{$\Sigma O C P{ }^{* *}$} & 2.3 & 1.8 & $(0.3-6.2)$ & 3.9 & 2.6 & $(0.3-10.4)$ \\
\hline & 349.5 & 286.7 & $(33.1-1027.7)$ & 531.9 & 375.3 & $(43.6-1593.1)$ \\
\hline \multirow[t]{2}{*}{ BDE-47 } & 0.1 & 0.2 & $(<0.03-0.7)$ & 0.2 & 0.3 & $(<0.03-0.9)$ \\
\hline & 10.2 & 29.8 & $(<4.3-115.4)$ & 27.4 & 35.5 & $(<4.3-95.7)$ \\
\hline \multirow[t]{2}{*}{$\Sigma \mathrm{POPs}^{* * *}$} & 14.9 & 29.0 & $(2.3-116.1)$ & 50.8 & 73.5 & $(3.9-275.3)$ \\
\hline & 2325.1 & 4533.2 & $(244.5-18134.5)$ & 5926.5 & 8645.2 & $(456.1-33985.0)$ \\
\hline $\mathrm{Hg}$ & 1.8 & 0.7 & $(0.7-3.7)$ & 1.9 & 0.8 & $(0.9-4.0)$ \\
\hline
\end{tabular}

${ }^{*} \Sigma \mathrm{PCBs}=\mathrm{CB} 101+\mathrm{CB} 138+\mathrm{CB} 153+\mathrm{CB} 180 ; * * \Sigma \mathrm{OCPs}=\mathrm{HCB}+\gamma-\mathrm{HCH}+4,4{ }^{\prime}-\mathrm{DDE}+2,4^{\prime}-\mathrm{DDT} ; * *{ }^{*} \mathrm{POPs}=\Sigma \mathrm{PCBs}+\Sigma \mathrm{OCPs}$ 
Table 2: Relationships between contaminants ( $\Sigma$ POPs and $\mathrm{Hg}$ ), sex, age, body-condition and interaction with sex as a function of CORT concentrations $\left(\mathrm{ng} \bullet \mathrm{ml}^{-1}\right)$ in incubating snow petrels: a) baseline, b) stress-induced and c) post-stress. $\mathrm{N}$ is the number of birds of each variable. Degrees of freedom vary between measures of CORT because model selection was performed by starting from the most general model that included all the variables/factors of interest and their interactions and we removed step by step the non-significant interactions, variables or factors.

\begin{tabular}{lllccc}
\hline Dependent variables & N & Independent variables & $D f$ & F & $p$-value \\
\hline \hline a) Baseline CORT & 36 & $\log (\Sigma$ POPs $)$ & 1,27 & 0.14 & 0.715 \\
& 49 & Sex & 1,47 & 1.2 & 0.279 \\
& 47 & Age & 1,44 & 0.2 & 0.66 \\
& 49 & Hg & 1,42 & 0.09 & 0.767 \\
& 48 & Body condition & 1,39 & 1.73 & 0.195 \\
& 36 & $\log (\Sigma$ POPs $) \times$ Sex & 1,26 & 0.46 & 0.505 \\
& 47 & Age $\times$ Sex & 1,43 & 3.49 & 0.068 \\
& 49 & Hg $\times$ Sex & 1,41 & 3.29 & 0.077 \\
& 49 & Body condition $\times$ Sex & 1,38 & 0.05 & 0.819 \\
\hline b) Stress-induced CORT & 36 & log $(\mathbf{\Sigma P O P s})$ & $\mathbf{1 , 3 4}$ & $\mathbf{6 . 1}$ & $\mathbf{0 . 0 1 9}$ \\
& 49 & Sex & 1,33 & 0.48 & 0.495 \\
& 47 & Age & 1,30 & 0.02 & 0.9 \\
& 49 & Hg & 1,28 & 0.01 & 0.915 \\
& 48 & Body condition & 1,31 & 2.82 & 0.103 \\
& 36 & $\log (\Sigma$ POPs $) \times$ Sex & 1,26 & 0 & 0.989 \\
& 47 & Age $\times$ Sex & 1,29 & 0.64 & 0.429 \\
& 49 & Hg $\times$ Sex & 1,27 & 0.21 & 0.653 \\
& 49 & Body condition $\times$ Sex & 1,32 & 3.97 & 0.055 \\
\hline d) Post-stress CORT & 36 & log $(\mathbf{\Sigma P O P s})$ & $\mathbf{1 , 3 4}$ & $\mathbf{5 . 1 7}$ & $\mathbf{0 . 0 2 9}$ \\
& 49 & Sex & 1,33 & 1.2 & 0.282 \\
& 47 & Age & 1,30 & 0.33 & 0.57 \\
& 49 & Hg & 1,27 & 0.03 & 0.863 \\
& 48 & Body condition & 1,31 & 1.37 & 0.25 \\
& 36 & $\log (\Sigma$ POPs $\times$ Sex & 1,32 & 1.51 & 0.228 \\
& 47 & Age $\times$ Sex & 1,29 & 1.34 & 0.257 \\
& 49 & Hg $\times$ Sex & 1,26 & 0 & 0.955 \\
& 49 & Body condition $\times$ Sex & 1,28 & 0.18 & 0.676 \\
\hline & & & &
\end{tabular}

